Kyoko Natori • Mayumi Tamari • Otsu Watanabe

Yoshihiro Onouchi $\cdot$ Yasuhisa Shiomoto $\cdot$ Shuji Kubo

Yusuke Nakamura

\title{
Mapping of a gene responsible for dermatitis in NOA (Naruto Research Institute Otsuka Atrichia) mice, an animal model of allergic dermatitis
}

Received: July 5, 1999 / Accepted: August 12, 1999

\begin{abstract}
The NOA (Naruto Research Institute Otsuka Atrichia) mouse is an animal model of allergic or atopic dermatitis, a condition characterized by ulcerative skin lesions with accumulation of mast cells and increased serum IgE. These features of the murine disease closely resemble human atopy and atopic disorders. We performed linkage analysis in NOA back-cross progeny, as a step toward identifying and isolating a gene responsible for the NOA phenotype. We crossed NOA mice with five other murine strains (C57BL/6J, IQI, C3H/HeJ, DBA/2J, and BALB/cByJ) and then bred back-cross animals. Using microsatellite markers, we scanned the entire genomes of $559 \mathrm{~N} 2$ offspring from the five parental strains. Linkage analysis revealed a significant association between ulcerative skin lesions and markers on murine chromosome 14. Statistical analysis indicated that the critical region was assigned to the vicinity of D14Mit236 and D14Mit160.
\end{abstract}

Key words Atopic dermatitis - Animal model · Linkage analysis $\cdot$ Chromosome 14

\section{Introduction}

Atopy and atopic disorders, multifactorial diseases resulting from combinations of genetic and environmental influences, have been increasing significantly in Western countries (Coleman et al. 1997). Genetic associations were noted many years ago through observations of familial ag-

K. Natori · M. Tamari · O. Watanabe · Y. Onouchi ·

Y. Nakamura $(\bowtie)$

Laboratory of Molecular Medicine, Human Genome Center,

Institute of Medical Science, University of Tokyo, 4-6-1

Shirokanedai, Minato-ku, Tokyo 108-8639, Japan

Tel. +81-3-5449-5372; Fax +81-3-5449-5433

e-mail: yusuke@ims.u-tokyo.ac.jp

Y. Shiomoto $\cdot$ S. Kubo

Naruto Research Institute, Otsuka Pharmaceutical Factory, Inc.,

Naruto, Japan gregation (Cooke and Vander Veer 1916; Rajka 1960). Although a large number of genetic investigations have been reported, the ways in which certain genes may predispose individuals to these diseases or contribute to their development are still not well understood because of the etiological complexity in humans. Hence, an animal model that develops a disease whose phenotype resembles human atopic diseases could be a promising approach. Appropriate murine models have already contributed to investigations into the pathogenesis of other multifactorial diseases in humans, such as asthma, diabetes mellitus, and essential hypertension (Blyth et al. 1996; Kloting et al. 1997; Joshi et al. 1997). From this point of view the Naruto Research Institute Otsuka Atrichia (NOA) mouse, a strain that develops severe ulcerative skin lesions that are associated with accumulation of mast cells, and also shows a significantly increased level of serum IgE (Kondo et al. 1997), is likely to be a good model for investigating genetic factors that underlie the development of severe allergic dermatitis.

From among various approaches we chose to attempt to localize such genes in NOA mice by linkage analysis. The mode of inheritance of dermatitis in NOA mice was recessive inheritance with incomplete penetrance. Here we report the chromosomal location of a major locus associated with the development of severe allergic dermatitis in this murine strain, and document evidence that differences in genetic background among the parental strains used for breeding back-cross animals significantly affected the incidence of skin lesions.

\section{Materials and methods}

Animals

NOA mice, a strain developed at the Naruto Research Institute Otsuka Pharmaceutical Factory, (Naruto, Japan), were bred at Clea Japan (Shirakawa, Japan). We crossed male NOA mice with female mice with five different genetic backgrounds (strains C57BL/6J, IQI, C3H/HeJ, DBA/2J, 
and $\mathrm{BALB} / \mathrm{cByJ}$ ). We then back-crossed only the female F1 progeny, because female NOA mice are unable to provide milk to their offspring due to dermatitis on their nipples. N2 offspring were examined for the absence or presence of ulcerative skin lesions.

Linkage studies

Genomic DNAs were isolated from the tail tips of the N2 population by standard techniques (Siracusa et al. 1989; Pavan and Tilghman 1994). We initially scanned the entire genome of each animal, using microsatellite markers selected at 10- to 20-cM intervals. Also examined were markers adjacent to genes whose homologues may be candidates for human atopic disorders, such as interleukin (IL)4 (Marsh et al. 1994), IL5 (Kapp and Zeck-Kapp 1991), IL4R (Hershey et al. 1997), HLA (Levine et al. 1972; Marsh et al. 1991; Blumenthal et al. 1992), and FCERI $\beta$ (Cookson et al. 1989; Sandford et al. 1993; Shirakawa et al. 1994). Primer sequences for amplifying each marker locus were obtained through the database at the Mouse Genome Informatics (MGI) web site (distributed via World Wide Web, URL: http://mgd.niai.affrc.go.jp/strtools.html). Oligonucleotide primers were synthesized by means of the Oligo $1000 \mathrm{M}$ DNA Synthesizer (Beckman, Palo Alto, CA, USA). Polymerase chain reaction (PCR) amplifications were performed as described by Dietrich and associates (1992). PCR conditions for most primers involved a denaturation step at $94^{\circ} \mathrm{C}$ for $2 \mathrm{~min}$, followed by 35 cycles of $94^{\circ} \mathrm{C}$ for $30 \mathrm{~s}, 55^{\circ} \mathrm{C}-$ $57^{\circ} \mathrm{C}$ for $30 \mathrm{~s}, 72^{\circ} \mathrm{C}$ for $30 \mathrm{~s}$, and extension at $72^{\circ} \mathrm{C}$ for $7 \mathrm{~min}$, in a Gene Amp PCR system 9,600 (Perkin Elmer Cetus, Norwalk, CT, USA). PCR products were electrophoresed on $4 \%$ agarose or $6 \%$ polyacrylamide gels, and stained with ethidium bromide.

\section{Statistical analysis}

The number of affected or non-affected mice, and whether each was a recombinant, were calculated for each marker locus. To identify the locus associated with dermatitis, the resulting segregation ratios were analyzed by the $\chi^{2}$ test.

\section{Results}

Among a total of 559 N2 offspring examined, 158 (28.3\%) developed ulcerative skin lesions (Table 1). These lesions developed as early as 6 weeks of age in DBA/2J, 13 weeks in BALB/cByJ, 18 weeks in IQI and C57BL/6J, and 24 weeks in $\mathrm{C} 3 \mathrm{H} / \mathrm{HeJ}$ descendants (Fig. 1). The incidence was not consistent with an autosomal recessive mode, and it clearly differed according to parental strain. The incidence of skin lesions when we used IQI (27.1\%), DBA/2J $(31.4 \%)$, or $\mathrm{BALB} / \mathrm{cByJ}(38.8 \%)$ as parental strains was about three times higher than that among C57BL/6J $(10.6 \%)$ or $\mathrm{C} 3 \mathrm{H} / \mathrm{HeJ}(12.2 \%) \mathrm{N} 2$ progeny.

In a whole-genome scan, using a total of 243 markers on 19 autosomal chromosomes, the number of informative

Table 1. Ratio of affected mice among N2 offspring

\begin{tabular}{lccl}
\hline Strain of F1 parent & Dermatitis + & Total & Susceptibility(\%) \\
\hline C57BL & 9 & 85 & 10.6 \\
IQI & 19 & 70 & 27.1 \\
C3H & 6 & 49 & 12.2 \\
DBA & 58 & 185 & 31.4 \\
BALB & 66 & 170 & 38.8 \\
& 158 & 559 & 28.3 \\
\hline
\end{tabular}

Fig. 1. Incidence of dermatitis in $\mathrm{N} 2$ offspring. The vertical axis indicates the ratio of the number of affected mice to the total number of N2 progeny. Strains: C57BL $(n=85$; diamonds; IQI $(n=70$; small rectangles on dashed line; $\mathrm{C} 3 \mathrm{H}(n=49 ;$ triangles; DBA $(n=$ 185 ; squares); BALB ( $n=170$; closed circles)

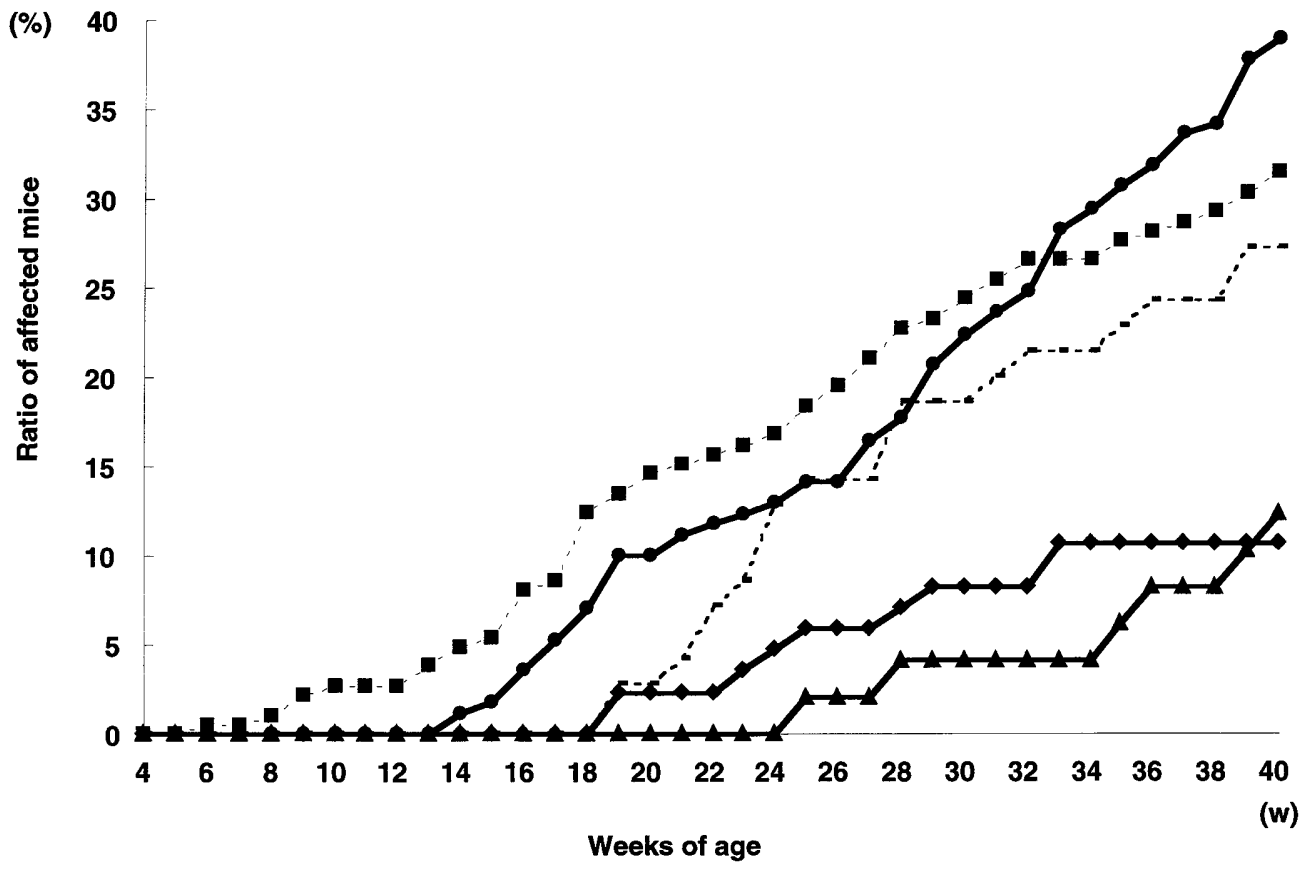


Fig. 2. Whole-genome scan, using 243 markers on 19 murine autosomes. The numbers of affected or non-affected mice, and whether recombinant or not, are shown for each marker locus. IL10 (interleukin 10), FcERI $\gamma$ (high-affinity immunoglobulin E receptor $\gamma$ ), FceRIa (high-affinity immunoglobulin E receptor $\alpha$ ), CD72 (CD72 antigen), TCR $\beta$ (T-cell receptor- $\beta$ ), IL4R (interleukin 4 receptor), IL4 (interleukin 4), IL5 (interleukin 5), $I g H$ (immunoglobulin $\mathrm{H}$ ), TCR $\gamma$ (T-cell receptor- $\gamma$ ), IL9 (interleukin 9), TCR $\alpha$ (Tcell receptor- $\alpha$ ), $M H C$ (major histocompatibility complex), and $F c \varepsilon R I \beta$ (high-affinity immunoglobulin $E$ receptor $\beta$ ) have been reported as candidate genes for atopic dermatitis in humans. Homo, Homozygous; hetero, heterozygous

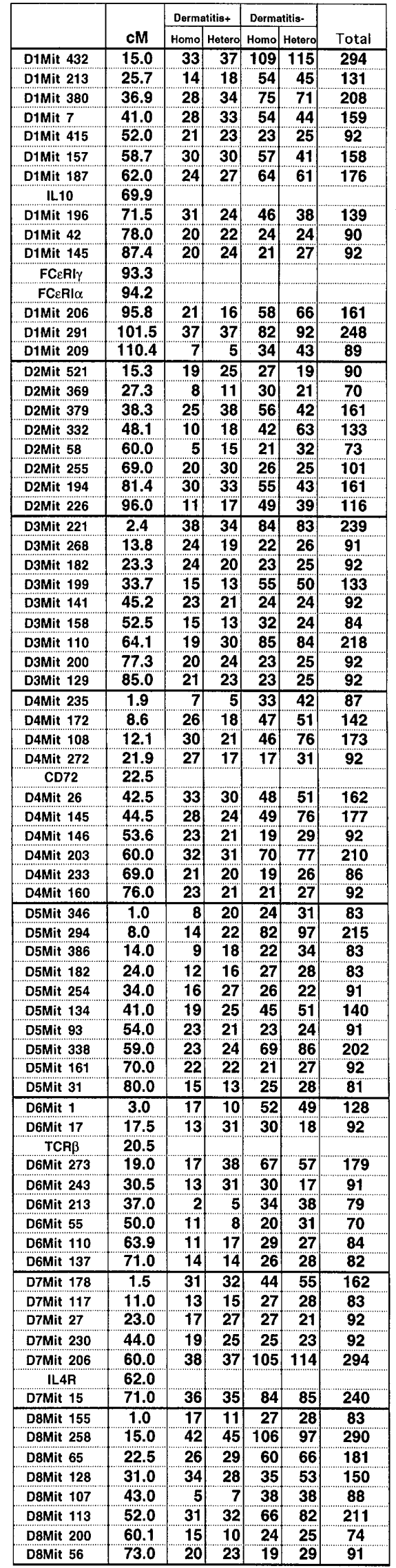


Table 2. Association of dermatitis and microsatellite markers on chromosome 14

\begin{tabular}{lrrrrrl}
\hline & \multicolumn{2}{l}{ Dermatitis(+) } & & \\
\cline { 2 - 4 } Primer & $\mathrm{cM}$ & Homo & Hetero & \multicolumn{1}{l}{$\chi^{2}$} & \multicolumn{1}{l}{$P$} \\
\hline D14Mit10 & 3.0 & 7 & 6 & 0.14 & 0.7040 \\
D14Mit14 & 10.0 & 44 & 18 & 13.47 & $<0.001$ \\
TCR $\alpha$ & 19.5 & & & & \\
D14Mit234 & 22.5 & 40 & 5 & 27.99 & $<0.001$ \\
D14Mit113 & 25.0 & 46 & 6 & 33.68 & $<0.001$ \\
D14Mit236 & 32.5 & 101 & 2 & 86.89 & $<0.001$ \\
D14Mit160 & 40.0 & 89 & 5 & 86.62 & $<0.001$ \\
D14Mit225 & 42.5 & 46 & 3 & 31.79 & $<0.001$ \\
D14Mit165 & 52.0 & 56 & 16 & 22.42 & $<0.001$ \\
\hline
\end{tabular}

Homo, Homozygous; hetero, heterozygous

cases at a given locus varied because informativeness at each locus was different depending on the parental strain from which the N2 progeny had been derived. We found no significant associations between dermatitis and any marker loci lying in regions syntenic to human chromosomal regions that contain candidate genes thought to be associated with human atopic disorders (Fig. 2). However, we found a significant linkage between skin lesions and markers in the middle of mouse chromosome 14. As shown in Table 2, the most likely position to contain alleles conferring susceptibility to dermatitis was assigned to the vicinity of D14Mit236 and D14Mit160 $\left(\chi^{2}=86.89 ; P<0.001\right.$ for D14Mit236 and $\chi^{2}=86.62 ; P<0.001$ for D14Mit160; Table 2).

\section{Discussion}

Atopy and atopic disorders are considered to be multifactorial diseases involving both genetic and environmental influences (Coleman et al. 1997). Since the environmental and nutritional conditions affecting atopic patients vary enormously, it is extremely difficult to identify genes that confer susceptibility or that are associated with the etiology of these diseases in humans. Hence, an animal model that resembles the human phenotype could contribute to investigations of the pathogenesis of atopic disorders. The NOA mouse can serve that function.

In the study reported here, the incidence of dermatitis in $\mathrm{N} 2$ offspring was higher when we crossed NOA mice with $\mathrm{BALB} / \mathrm{cByJ}$, IQI, or DBA/2J strains than when C57BL/6J and $\mathrm{C} 3 \mathrm{H} / \mathrm{HeJ}$ mice were the parental strains (Table 1 ). Moreover, the age of disease onset in descendants of $\mathrm{BALB} / \mathrm{cByJ}$ or $\mathrm{DBA} / 2 \mathrm{~J}$ mice was earlier than in the others (Fig. 1). Recently, Leung (1997) reported that the immunoregulatory disorder known as atopic dermatitis in humans resulted from an imbalance of the helper $\mathrm{T}$ lymphocytes that release cytokines. At present, murine and human CD4+ T-helper cells are classified as either Th- 1 or Th-2 on the basis of their cytokine-expression profiles (Mosmann et al. 1986). Th-1 cells are characterized by the secretion of $\gamma$-interferon (IFN- $\gamma$ ); Th- 2 cells are known to produce interleukin (IL)-4. IFN- $\gamma$ inhibits the differentia- tion of Th-2 cells and suppresses IgE synthesis (Vercelli and Geha 1993; Lung 1997). Thepen et al. (1996) have indicated that elevated production of IgE and Th-2 cytokines plays an important role in the pathogenesis of atopic dermatitis. Among the five mouse strains we mated with the NOA mice, BALB/cByJ and DBA/2J are known to have Th-2dominant immunity (Heinzel et al. 1993; Shankar and Titus 1995). The N2 progeny from those parental lines exhibited a higher incidence and earlier onset of the disease than did descendants of $\mathrm{C} 57 \mathrm{BL} / 6 \mathrm{~J}$ or $\mathrm{C} 3 \mathrm{H} / \mathrm{HeJ}$ mice, which carry Th-1-dominant immunity (Heinzel et al. 1993; Shankar and Titus 1995). Our results therefore support the idea that Th2 dominant immunity increases susceptibility to, and is associated with, atopic dermatitis.

Among a total of 158 affected mice examined, $153 \mathrm{had}$ a hairless phenotype. Therefore we examined the Hairless ( $h r$ gene on mouse chromosome 14 (Cachon-Gonzalez et al. 1994) for its level of expression and possible genetic alterations. However, as we found no genetic changes or altered levels of expression in those experiments, it is unlikely that $h r$ plays any important role in dermatitis among NOA mice.

Our linkage study based on genome-wide scanning strongly indicated that a gene capable of conferring susceptibility to atopic dermatitis lies within an interval of approximately $17.5 \mathrm{cM}$ between D14Mit113 and D14Mit225 on mouse chromosome 14. The murine T-cell receptor-alpha $(T C R-\alpha)$ gene, whose product modifies specific $\operatorname{IgE}$ responses (Moffatt et al. 1994), is located in the proximal part of the candidate region. However, markers D14Mit14 and D14Mit234 near the TCR- $\alpha$ locus revealed relatively frequent recombination with respect to the dermatitis phenotype, while distal markers were involved in fewer recombination events. Therefore we assume that TCR- $\alpha$ is not a likely candidate for dermatitis in NOA mice. A computer search of databases, including the mouse-human comparative map, failed to identify in the region any other murine homologues of genes that had been reported as candidates for this disease in humans. Nevertheless, since this $17.5-\mathrm{cM}$ region of murine chromosome 14 must contain dozens of genes, it will be useful to construct a more detailed genetic map with a view toward positional cloning of the putative dermatitis-associated gene.

Acknowledgments This work was supported in part by grants from the Ministry of Health and Welfare of Japan, and the Ministry of Education, Culture and Science of Japan.

\section{References}

Blumenthal MN, Marcus-Bagley D, Awdeh Z, Johnson B, Yunis EJ, Alper CA (1992) HLA-DR2, [HLA-B7, SC31, DR2], and [HLA-B8, SC01, DR3] haplotypes distinguish subjects with asthma from those with rhinitis only in ragweed pollen allergy. J Immunol 148:411-416

Blyth DI, Pedrick MS, Savage TJ, Hassel EM, Fattah D (1996) Lung inflammation and epithelial changes in a murine model of atopic asthma. Am J Respir Cell Mol Biol 14:425-438

Cachon-Gonzalez MB, Fenner S, Coffin JM, Moran C, Best S, Stoye JP (1994) Structure and expression of the hairless gene of mice. Proc Natl Acad Sci USA 91:7717-7721 
Coleman R, Trembath RC, Harper JI (1997) Genetic studies of atopy and atopic dermatitis. Br J Dermatol 136:1-5

Cooke R, Vander Veer A (1916) Human sensitization. J Immunol 1:201-305

Cookson WOCM, Sharp PA, Faux JA, Hopkin JM (1989) Linkage between immunoglobulin-E responses underlying asthma and rhinitis at chromosome 11q. Lancet 337:1292-1295

Dietrich W, Katz H, Lincoln SE, Shin H-S, Friedman J, Dracopoli NC, Lander ES (1992) A genetic map of the mouse suitable for typing intraspecific crosses. Genetics 131:423-447

Heinzel FP, Schoenhaut DS, Rerko RM, Rosser LE, Gately MK (1993) Recombinant interleukin 12 cures mice infected with Leishmania major. J Exp Med 177:1505-1509

Hershey GK, Friedrich MF, Esswein LA, Thomas ML, Chatila TA (1997) The association of atopy with a gain-of-function mutation in the alpha subunit of the interleukin-4 receptor. N Engl J Med 337:1720-1725

Joshi RL, Lamothe B, Bucchini D, Jami J (1997) Genetically engineered mice as animal models for NIDDM. FEBS Lett 401:99-103

Kapp A, Zeck-Kapp G (1991) Interleukin-5-induced granulocyte activation in atopic patients. Br J Dermatol 125: 108-115

Kloting I, Berg S, Kovacs P, Voigt B, Vogt L, Schmidt S (1997) Diabetes and hypertension in rodent models. Ann NY Acad Sci 827:64-84

Kondo T, Shiomoto Y, Kondo T, Kubo S (1997) The NOA mouse: a new hair-deficient mutant (a possible animal model of allergic dermatitis). Mouse Genome 95:698-700

Leung DYM (1997) Atopic dermatitis: immunobiology and treatment with immune modulators. Clin Exp Immunol 107:25-30

Levine BB, Stember RH, Fotino M (1972) Ragweed hay fever: genetic control and linkage to HLA haplotypes. Science 178:12011203

Marsh DG, Zwollo P, Huang SK (1991) Molecular and cellular studies of human immune responsiveness to the short ragweed allergen, Amb a V. Eur Respir J Suppl 13:60s-67s

Marsh DG, Neely DJ, BreaZeale DR (1994) Linkage analysis of IL-4 and other chromosome 5q31.1 markers and total serum immunoglo- bulin E concentrations. Science 264:1152-1156

Moffatt MF, Hill MR, Cornelis F, Schou C, Faux JA, Young RP, James AL, Ryan G, Soufe P, Musk AW, Hopkins JM, Cookson WOCM (1994) Genetic linkage of T-cell receptor $\alpha / \beta$ complex to specific IgE responses. Lancet 343:1597-1600

Mosmann TR, Cherwinski H, Bond MW, Giedlin MA, Coffman RL (1986) Two types of murine helper Tcell clones. I. Definition according to profiles of lymphokine activities and secretory proteins. J Immunol 136:2348-2357

Pavan WJ, Tilghman SM (1994) Piebald lethal (sl) acts early to disrupt the development of neural crest-derived melanocytes. Proc Natl Acad Sci USA 91:7159-7163

Rajka G (1960) Prurigo Besnier (atopic dermatitis) with special reference to the role of allergic factors. Acta Derm Venereol (Stockh) 40:285-306

Sandford AJ, Shirakawa T, Moffatt MF, Daniels SE, Ra C, Faux JA, Young RP, Nakamura Y, Lathrop GM, Cookson WOCM, Hopkin JM (1993) Localisation of atopy and beta subunit of high-affinity IgE receptor (FceRI) on chromosome 11q. Lancet 341:332-334

Shankar AH, Titus RG (1995) T cell non-T cell compartments can independently determine resistance to Leishmania major. J Exp Med 181:845-855

Siracusa LD, Buchberg AM, Copeland NG, Jenkins NA (1989) Recombinant inbred strain and interspecific backcross analysis of molecular markers flanking the murine agouti coat color locus. Genetics 122:669-679

Shirakawa T, Li A, Dubowitz M, Dekker JW, Shaw AE, Faux JA, Ra C, Cookson WOCM, Hopkin JM (1994) Association between atopy and variants of the $\alpha / \beta$ subunit of the high-affinity immunoglobulin $\mathrm{E}$ receptor. Nat Genet 7:125-130

Thepen T, Langeveld-Wildschut EG, Bihari IC, Wichen DF, van Rejisen FC, Mudde GC, Bruijnzeel-Koomen CA (1996) Biphasic response against aeroallergen in atopic dermatitis showing a switch from an initial TH2 response to a TH1 response in situ: an immunocytochemical study. J Allergy Clin Immunol 97:828-837

Vercelli D, Geha RS (1993) Regulation of IgE synthesis: from membrane to the genes. Springer Semin Immunopathol 15:5-16 